\title{
Influence of post-mortem aging in tenderness of chicken breast fillets
}

\author{
Influência da maturação post-mortem sobre a tenderização de filés de peito de frango
}

\author{
Helena Caminha Santos ${ }^{1}$ Adriano Brandelli ${ }^{1}$ Marco Antônio Záchia Ayub ${ }^{1}$
}

\begin{abstract}
In this work, analysis of chicken breast fillets was performed for shear values and sensory evaluation after different times of aging. Aging process was carried out by holding carcasses in covered plastic boxes, in a cold room, at $3+/-1{ }^{\circ} C$; groups of 5 carcasses were stored and classified according to the period of storage in cold room as 0 (control), 2, 4, 8, 12 and 24 hours. The variation in $\mathrm{pH}$ of chicken carcasses during rigor decreased from 6.4 to 5.9. However, during the process of aging, the $\mathrm{pH}$ values increased up to 6.2 in the first $12 \mathrm{~h}$, probably as the result of proteolysis. The Warner-Bratzler shear values decreased as aging time increases, resulting in a first order kinetic. The carcasses presented a more accentuated decline in shear values in the first two hours of aging. After this period, the curve had a similar performance, achieving values of less than $1 \mathrm{kgf}$ in 4 hours or more, with complete aging being accomplished at 8 hours. The samples with higher period of aging (8,12 and 24 hours) were preferred in sensorial analysis, without significant differences among them.
\end{abstract}

Key words: chicken breasts; meat tenderization; sensory evaluation.

RESUMO

Neste trabalho, foram estudados os efeitos de diferentes tempos de maturação post-mortem sobre os valores de ruptura tecidual (cisalhamento) e avaliação sensorial de filés de peito de frango. O processo de maturação foi realizado pela manutenção das carcaças em caixas fechadas de plástico e armazenadas a $3 \pm 1{ }^{\circ} \mathrm{C}$. Grupos de 5 carcaças foram classificados de acordo com o período de armazenagem na câmara fria como 0 (controle), 2, 4, 8, 12 e 24 horas. Os valores de $\mathrm{pH}$ das carcaças durante o período do rigor post-mortem decresceram de 6,4 para 5,9 , enquanto que, durante o subseqüente período de maturação, os valores voltaram a crescer, atingindo um $\mathrm{pH}$ de 6,2 após 12 horas, provavelmente como resultado da proteólise. Os valores de cisalhamento de Warner-Bratzler decresceram inversamente ao tempo de maturação, de acordo com uma reação cinética de primeira ordem, apresentando um declínio mais acentuado nos valores de cisalhamento nas primeiras duas horas de maturação, após o qual o desempenho tendo sido similar para todos os grupos, atingindo valores inferiores a $1 \mathrm{kgf}$ em 4 horas ou mais, com a maturação completa sendo atingida em 8 horas. As amostras com períodos maiores de maturação (8, 12 e 24 horas) foram preferidas na análise sensorial, sem diferenças significativas entre elas.

Palavras-chave: peito de frango; tenderização de carnes; avaliação sensorial.

\section{INTRODUCTION}

The characteristics of poultry production and processing have changed dramatically over the last decades. In 1965 , more than $96 \%$ of all poultry meat sold in the USA was in the form of whole, readyto-cook carcasses or as raw pieces. In 1997, less than $65 \%$ of the broiler meat was sold in that form, and $35 \%$ was marketed as processed products. In the past, many of the raw poultry parts for sale at fast food restaurants have been marinated, breaded, or battered at the point of sale. However, with the growth of the processing industry, there has been a trend towards performing many of these steps at the food processing plant (YOUNG \& LION, 1997).

The global changes in poultry marketing during the last 30 years have turned Brazil into an important producer and supplier of industrialized chicken products. Present numbers show Brazil as the second largest producer $(7,500$ thousand tons/year) and exporter (1,600 thousand tons/year) of chicken meat and products (ABEF, 2003). Therefore, to continue to be one of the leaders in the international

${ }^{1}$ Engenharia de Alimentos, Instituto de Ciência e Tecnologia de Alimentos, Universidade Federal do Rio Grande do Sul, CP 15090, 91501970, Porto Alegre, RS, Brasil. E-mail: mazayub@ufrgs.br 
market, the industry must adapt to new, higher standards of quality. Achieving this standard is the maintenance of competitive position in market.

The objective of poultry industry is to offer a tender, juicy, with good flavor and color product and the warranty of a stable shelf-life (OLIVO, 1999). Of great concern is the period of time between slaughter and deboning. Research has demonstrated that lean beef carcasses chilled slowly had more tender muscles than the ones chilled fast (DIKEMAN, 1996), with meat aging contributing to the meat tenderness (MILLER et al., 1997). However, the aging operation is expensive and today's processing plants have been forced to reduce this time to a minimum (SAMS, 2001). Not well-controlled aging, such as earlier deboning or short aging times, results in an increase of meat toughness, which is highly undesirable.

Although the process of meat tenderness during post-mortem refrigerated storage of carcasses is a well-known process, the mechanism through which these changes are brought remains elusive and controversial. The post-mortem tenderization is a complex process, affected by a large number of variables, such as animal age and gender, rate of glycolysis, amount and solubility of collagen, sarcomere length, ionic strength, and degradation of myofibrillar proteins (KOOHMARAIE, 1994; GOLL et al., 1997). The post-mortem proteolysis is responsible for most of tenderization that occurs later during aging (KOOHMARAIE, 1996). Proteolysis is an important factor contributing to post-mortem changes in skeletal muscle, including meat tenderness. In the past it was assumed that the normal post-mortem accumulation of lactic acid causes the lysossomal membrane to become fragile and leak enzymes that have the potential to cause myofibrillar weakening. More recently, it has been proposed that the physiological changes in post-mortem muscle that correlates with improvement in meat tenderness are the result of $\mathrm{Z}$-lines, troponin- $\mathrm{T}$, titin and desmin degradations, besides the formation of $95 \mathrm{kDa}$ and 30 kDa proteins (KOOHMARAIE, 1994). Several protease systems within the muscle could be involved in the post-mortem tenderization process (OUALI, 1992). The role of each of these systems in the aging process is still debated but sarcoplasmic calciumdependent calpains have been suggested to be the main proteases (KOOHMARAIE, 1996).

Catheptic enzymes (cathepsins) are located within lysossomes and are able to act at the $\mathrm{pH}$ of meat to degrade myofibrillar proteins (primarily myosin and actin), producing a tender product. Calpains, found in the sarcoplasm of myofibrills, known as calcium-activated proteases, require calcium ions $\left(\mathrm{Ca}^{+2}\right)$ for activity. These enzymes require specific conditions (e.g.; temperature, $\mathrm{pH}$ ) for optimal activity. If these conditions could be controlled in meat, improving meat tenderness can be achieved (GOLL et al., 1997).

The purpose of this study was to determine the effect of controlled post-mortem aging on the tenderness of chicken breast fillet. A major emphasis was to determine the minimum period of time necessary to observe an increase in tenderness and standardizing the procedure in the poultry processing plant.

\section{MATERIALS AND METHODS}

\section{Sample preparation}

Thirteen Ross female birds of 36 days and with $1.1+/-0.1 \mathrm{~kg}$ were processed in a commercial poultry plant. They were stunned (60 V AC for $10 \mathrm{~s})$, killed by exsanguination (bled for $2 \mathrm{~min}$ ), scalded for 2 min at $60^{\circ} \mathrm{C}$, mechanically picked and eviscerated. They were immediately chilled for 50 to 60 minutes, in cold water at $2+/-1^{\circ} \mathrm{C}$. During slaughter and aging the $\mathrm{pH}$ and temperature of the carcasses were measured by a combined $\mathrm{pH}$ meter-thermometer Testo 230 . The measures were done by insertion of the sensor in the upper part of the chicken breast, during industrial slaughter process.

Aging process was carried out by holding carcasses in covered plastic boxes, in a cold room, at $3+/-1^{\circ} \mathrm{C}$, (CASON et al., 1997; LESIAK et al., 1997; YAMAMOTO \& PEARCE, 1988; CRAIG et al., 1999). Groups of 5 carcasses were stored and classified according to the period of storage in cold room as 0 (control), 2, 4, 8, 12 and 24 hours. Immediately after each period, the five carcasses were skinned, and the Pectoralis major muscles were removed. The P. major breast muscle or each breast fillet were individually vacuum packed and frozen at a temperature of $-25^{\circ} \mathrm{C}$, for 40 minutes, in a Gyrofreezer.

Each chicken breast fillet was cooked while yet frozen, in cooking bags, by immersion in boiling water bath until internal endpoint of $80^{\circ} \mathrm{C}$, for approximately 45 minutes. The temperature was measured with cooking thermometer inserted into the thickest part of the breast fillet. After cooked, the samples were cooled in an ice bath for 30 minutes, and stored overnight, for approximately 12 hours, in a temperature of $2+/-1^{\circ} \mathrm{C}$. This storage was done to warrant the best manipulation during shearing, to be sure that the fiber kept its integrity when the equipment cut them off. 


\section{Texture evaluation procedures}

The measurements of shear values were carried out after the chicken breast fillet (P. major) achieved $5+/-1^{\circ} \mathrm{C}$. Three cylinders of $1.27 \mathrm{~cm}$ of diameter were removed parallel to the fibre orientation through the thickest portion of the cooked muscle of each chicken breast fillet (P. major). A Warner-Bratzler apparatus was used to measure the shear value. The maximum shear force is registered on a scale by a dynamometer. Data were processed using the Dransfield model resulting in the equation $\mathrm{T}_{\mathrm{D}}=0.65+3.12 \mathrm{e}^{-0.557}$. Each point represents the mean of five independent determinations.

\section{Sensory quality analysis}

After cooking, the samples of chicken breast fillet (P. major) were cut in pieces of $1.5 \times 1.0$ $\mathrm{cm}$ and served hot, for 16 members non-trained of a descriptive attribute panel evaluation, in an individual workstation of a testing room. They evaluated cohesion, juicyness and tenderness, each attribute receiving a note in a special scale from 1 to 5 , where 1 was awful, 3 good and 5 excellent.

\section{Statistical analysis}

A total of 30 chicken breast fillets ( 5 for each treatment) were submitted to shear value, in triplicates. The data were statistically analysed by Tukey-Kramer test (ANOVA), using the GraphPad software, with $\mathrm{p}<0.05$. The sensorial data were submitted to the analysis of Tukey-Kramer test (ANOVA), GraphPad software, with $\mathrm{p}<0.05$ to compare the sensorial results. For the graph results, each point represents the mean of five independent determinations.

\section{RESULTS AND DISCUSSION}

\section{Variations in the $\mathrm{pH}$ values of carcasses}

The variation in $\mathrm{pH}$ of chicken carcasses during rigor is shown in Fig. 1 (a). As it can be seen, there is a sharp decrease of $\mathrm{pH}$ as a result of glycolysis, lactic acid formation and the reduction of oxygen lability in muscle. This result is in agreement with other studies (CASSENS, 1994; SCHREURS, 2000). OLIVO (1999) described that the low rate in $\mathrm{pH}$ decline indicates that the animals are not under stress when slaughtered; this is often associated with increased meat tenderness (ALI et al., 1999). For nonstressed birds the $\mathrm{pH}$ achieved the end value after approximately 30 minutes of slaughter achieving a $\mathrm{pH}$ around 5.6 and 6.0. However, during the process of aging, the curve of $\mathrm{pH}$ shown in figure $1(\mathrm{~b})$, indicates an increase in values, probably as the result of proteolysis, as it has been suggested by CRAIG et al. (1999). It has been postulated that slower rates of decline in $\mathrm{pH}$ is the consequence of a temporary decrease in the anaerobic glycolysis, because a sudden relaxation in the muscle caused by cutting would reduce the need for high ATP concentrations in the tissue (ALI et al., 1999). However, a lack of correlation between the $\mathrm{pH}$ at the time of boning and the shear values of broiler Pectoralis superficialis muscle (STEWART et al., 1984), suggests that the postmortem metabolism and the development of rigor mortis is different in chicken breast tissue than in "redmeat" muscles.

Many studies have been concentrated on the processes occurring in mammalian tissue and those mainly on beef, with little attention at the changes taking place in poultry muscle. Muscle, and thus

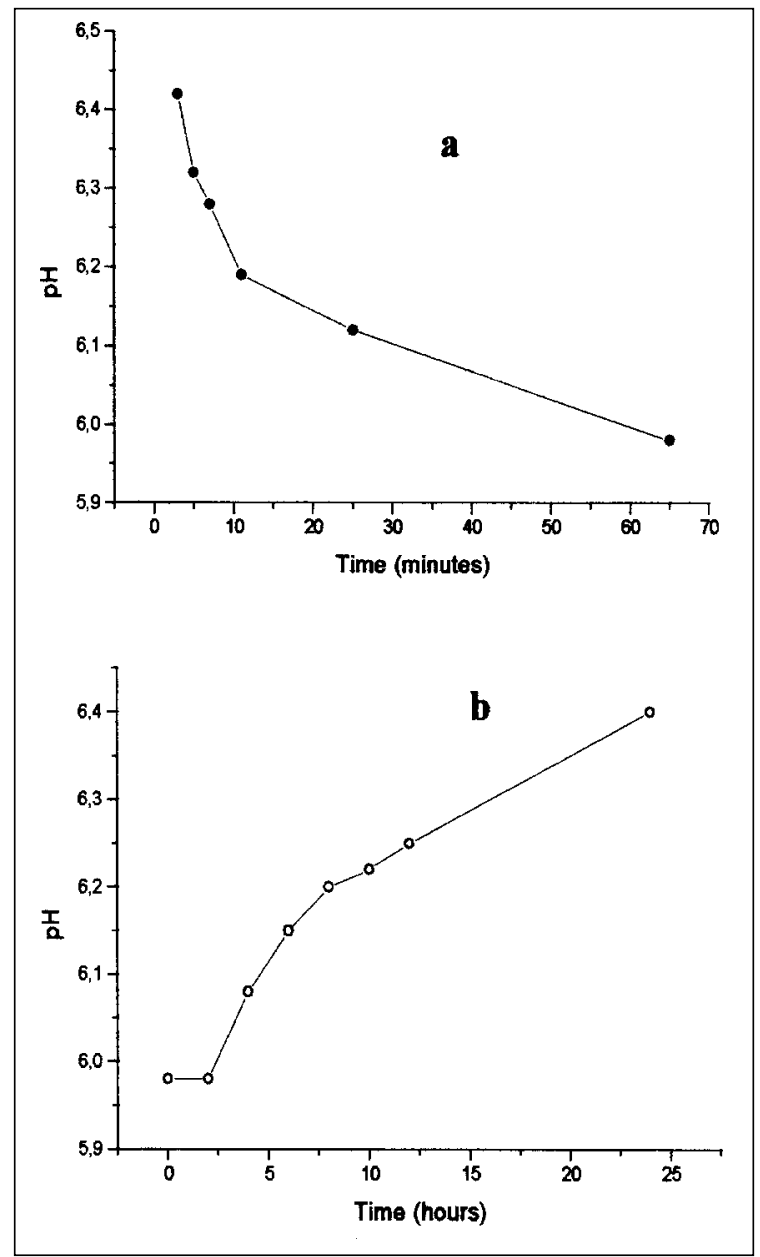

Figure 1 - VARIATION IN pH DURING RIGOR (a) and AGING (b). $\mathrm{pH}$ values were measured in carcasses after slaughtering and processing.

Ciência Rural, v.34, n.3, mai-jun, 2004. 
protein, accumulation is achieved through a dynamic equilibrium between synthesis and degradation. Based on this property, it has been proposed that breast muscle of poultry is especially suited to study the effects of post-mortem proteolytic degradation on meat aging and product quality (SCHREURS, 2000).

\section{Variations in the temperature values of carcasses}

Temperatures of carcasses were measured during the industrial process of carcass preparation. Results shown in figure 2 (a) indicate a rapid decline of temperature from $40^{\circ} \mathrm{C}$ to $20^{\circ} \mathrm{C}$ in the first 25 minutes, since chilling was in use. The carcasses were further chilled from $20^{\circ} \mathrm{C}$ to $10^{\circ} \mathrm{C}$ before they were conditioned to aging. During aging, the temperature began in $10^{\circ} \mathrm{C}$ and decreased to $5^{\circ} \mathrm{C}$ after 24 hours, as shown in figure 2 (b). This range warranted the

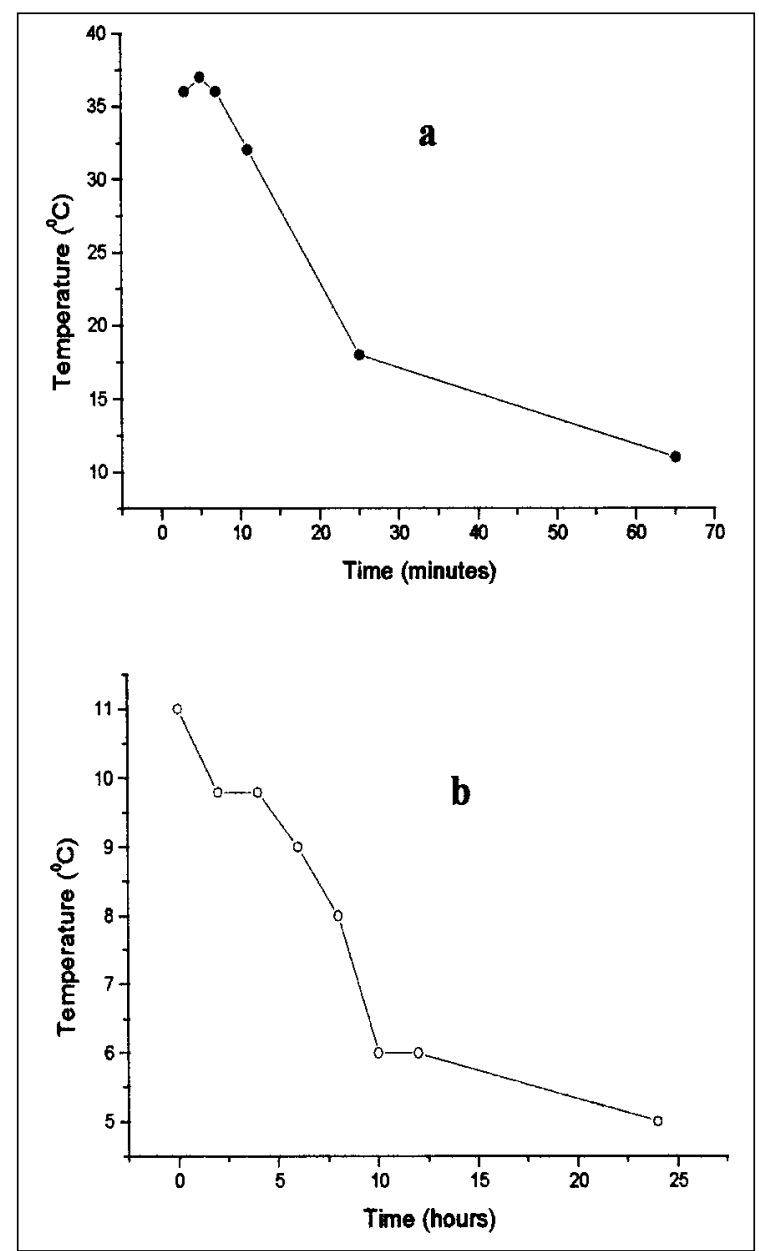

Figure 2 - VARIATION IN TEMPERATURE DURING RIGOR (a) and AGING (b). Temperature values were measured in carcasses after slaughtering and processing. conditions for biochemical changes. The chilling regimen had no major effect on $\mathrm{pH}$ values of $P$. major muscle of processed broilers, although longer sarcomeres, lower cooking losses, and shear force values were observed with fast chilling (DUNN et al., 2000).

\section{Impact of aging over tenderness of carcasses}

The post-chilling aging had a very important impact over shear values of carcasses, as shown in Fig. 3. According to previous studies where non-aging products were compared (YAMAMOTO \& PEARCE, 1988; KOOHMARAIE, 1992; DIKEMAN, 1996), the Warner- Bratzler shear values decreases as aging time increases. In this present work, the carcasses showed a more accentuated decline in shear values in the first two hours of aging. After this period, the curve had a similar performance, achieving values of less than $1 \mathrm{kgf}$ in 4 hours or more. The kinetic obtained by us is similar to the Dransfield Model for bovines (DRANSFIELD, 1992; GOLL et al., 1997) where it is discussed that the tenderness is obtained at different times of post-mortem to a general first-order rate equation as $\mathrm{T}=\mathrm{T}_{0} \mathrm{e}^{-\mathrm{kt}}$, where $\mathrm{T}_{\mathrm{t}}$ is tenderness at some post-mortem time, $\mathrm{T}_{0}$ is the temperature at death, $\mathrm{k}$ is a rate constant and $t$ is the variation of time. DRANSFIELD (1992) postulated that the change in tenderness during the period of accentuated decline is not just due to proteolysis, but also as a consequence of actin/myosin cross-bridge interaction from resting (weak) state to a contractile (strong) muscle state, followed by a gradual weakening of the contractile muscle state having, therefore, an important role on meat tenderness. As can it be seen in figure 3, our

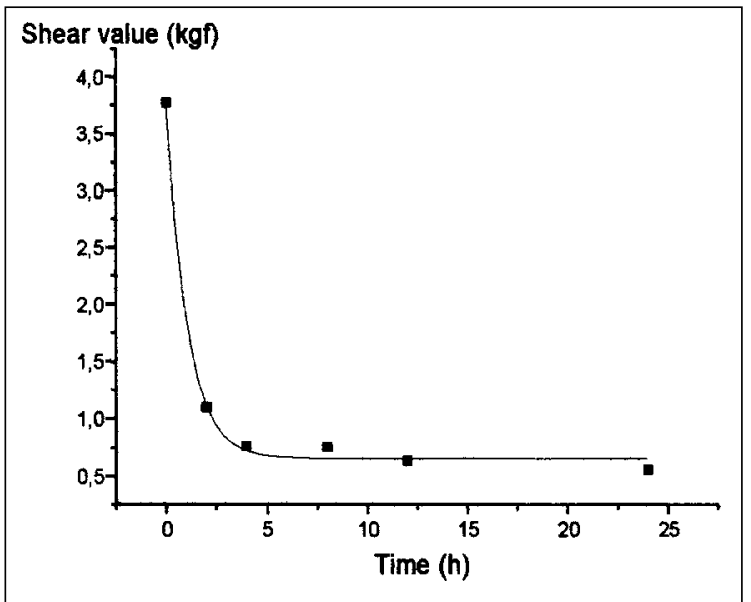

Figure 3 - SHEAR VALUES OF CHICKEN CARCASSES DURING AGING. Samples of chicken breast fillets were prepared as described in Material and Methods. 
results predict remarkably well with this model being therefore, applicable to poultry processing.

\section{Impact of tenderness on sensorial analysis}

In order to correlate the tenderness with the general acceptance of the products, sensorial analysis of different samples in reference to texture is shown in Table 1. Although the results for shear value showing complete tenderization being achieved between 4 and 8 hours, the samples with higher period of aging (8, 12 and 24 hours) were preferred in sensorial analysis. Similar results were obtained by other researchers who used aging periods of up to 24 hours under temperatures between 0 and $5^{\circ} \mathrm{C}$ (FRONING et al., 1978; McKEE \& SAMS, 1998, OLIVO, 1999). In their works, products which were aged and marinated, or injected, could be aged for at least 4 hours at temperatures between 0 and $5^{\circ} \mathrm{C}$, treatment that guarantees similar results to the ones with 8 hours, being therefore favorable from the point of view of reducing processing time.

While SAMS (2001) states that general industrial practice adopts a minimum of 4 hours of aging for poultry meat, FAUSTMAN (1994) suggests that the aging period depends on the type of meat and, for poultry, the ideal time would be of 1 to 2 days of aging. Results obtained in this research allow us to suggest a reduction of 12 to 16 hours in the aging period, still achieving a similar acceptability, if we consider that there is no significant difference between 8, 12 and 24 hours of aging on sensorial analysis as shown in Table 1. The reduction on the industrial processing period could be even higher, to about up to 20 hours, if we just consider the shear force values that, after 4 hours of aging, is more than $80 \%$ lower compared with the control (meat without aging).

Table 1 - Variations of Sensorial Tenderness of Chicken Breast Fillets With Carcass Aging.

$\begin{array}{ll}\text { Carcass Aging Time } & \begin{array}{l}\text { Sensorial Tenderness Scores for Chicken } \\ \text { Breast Fillets }\end{array}\end{array}$

\begin{tabular}{lc}
\hline (h) & (Carcasses with $1.0+/-0.1 \mathrm{~kg})$ \\
\hline 0 & $1.75^{\mathrm{d}}$ \\
2 & $2.65^{\mathrm{c}}$ \\
4 & $3.06^{\mathrm{bc}}$ \\
8 & $3.69^{\mathrm{ab}}$ \\
12 & $4.00^{\mathrm{a}}$ \\
24 & $4.13^{\mathrm{a}}$ \\
\hline
\end{tabular}

\footnotetext{
${ }^{\mathrm{a}-\mathrm{d}}$ Means in each column with no common superscript differ significantly $(\mathrm{p}<0.05) ; \mathrm{n}=16$.
}

\section{CONCLUSIONS}

In our research, the aged samples of chicken breast fillets presented higher tenderness when compared with non-aged samples. The ideal period of aging time can be set to 8 hours, since there is no further quality gain after this time, as determined by the sensorial tenderness scores. In this way, even microbiological problems can be avoided due to the short aging time. This aging period could be used for products that are going to be commercialized without further processing.

\section{REFERENCES}

ABEF. Estatísticas. Captured in 16 july 2003. Online. Available at http://www.abef.com.br.

ALI, A.S.A.; HARRISON, A.P; JENSEN, J.F. Effect of some antemortem stressors on peri-mortem and post-mortem biochemical changes and tenderness in broiler breast muscle: a review. W Poultry Sci J, Mont Morris, v.55, p. 403-414, 1999.

CASON, J.A.; LYON, C.E.; PAPA, C.M. Effect of muscle opposition during rigor on development of broiler breast meat tenderness. Poultry Sci, Blacksburg, v.76, p.785-787, 1997.

CASSENS, R.C. Meat preservation. Preventing losses and assuring safety. Trumbull : Food and Nutrition, 1994. 33p.

CRAIG, E.W.; FLETCHER, D.L.; PAPINAHO, P.A. The effects of antemortem electrical stunning and post-mortem electrical stimulation on biochemical and textural properties of broiler breast meat. Poultry Sci, Blacksburg, v.78, p.490494, 1999

DIKEMAN, M.E. The relationship of animal leanness to meat tenderness. Reciprocal Meat Conference, Savoy, v.49, p.87105, 1996.

DRANSFIELD, E. Modeling post-mortem tenderization. III Role of calpain in conditioning. Meat Sci, Savoy, v.31, p.57$73,1992$.

DUNN, A.A. et al. Relationship between early post-mortem muscle $\mathrm{pH}$ and shortening-induced toughness in the Pectoralis major muscle of processed broilers air-chilled at $0^{\circ} \mathrm{C}$ and $-12{ }^{\circ} \mathrm{C}$. Braz J Poultry Sci, Campinas, v.41, p.53-60, 2000.

FAUSTMAN, L.C. Post-mortem changes in muscle foods. In: KINSMAN, D.M. et al. The effect of preslaughter temperature, stress, stuggle and anesthetization on color and textural characteristics of turkey muscle. Poultry Sci, Blacksburg, v.57, p.630-633, 1978 .

GOLL, D.E.; BOEHM, M.L.; GEESINK, G.H. What causes postmortem tenderization? Reciprocal Meat Conference, Savoy, v.50, p.60-67, 1997.

KOOHMARAIE, M. Role of the neutral proteinases in postmortem muscle protein degradation and meat tenderness. Reciprocal Meat Conference, Savoy, v.45, p.63-71, 1992.

Ciência Rural, v.34, n.3, mai-jun, 2004. 
KOOHMARAIE, M. Muscle proteinases and meat aging. Meat Sci, Savoy, v.38, p.93-104, 1994.

KOOHMARAIE, M. Biochemical factors regulating the toughening and tenderization processes of meat. Meat Sci, Savoy, v.43, S193-S201, 1996.

LESIAK, M.T. et al. Effects of post-mortem time before chilling and chilling temperatures and texture of turkey breast muscle. Poultry Sci, Blacksburg, v.76, p.552-556, 1997.

McKEE, S.R.; SAMS, A.R. Rigor mortis development at elevated temperatures induces pale, soft and exudative turkey characteristics. Poultry Sci, Blacksburg, v.77, p.169-174, 1998.

MILLER, R.K. et al. Method for Improving meat tenderness. Reciprocal Meat Conference, Savoy, v.49, p.106-121, 1997.

OLIVO, R. Carne PSE em frangos. 1999. 97f. Tese (Ph.D em Ciências dos Alimentos) - Faculdade de Ciências Farmacêuticas, Universidade de São Paulo.
OUALI, A. Proteolytic and physicochemical mechanisms involved in meat texture development. Biochimie, Paris, v.74, p.251-265, 1992.

SAMS, A.R. Second processing: parts, deboning, and portion control. In: SAMS, A.R. Poultry meat processing. New York: CRC, 2001.

SCHREURS, F.J.G. Post-mortem changes in chicken muscle. W Poultry Sci J, Mont Morris, v.56, p.319-346, 2000.

STEWART, M.K. et al. The effect of hot boning broiler breast meat muscle on post-mortem pH decline. Poultry Sci, Blacksburg, v.63, p.2181-2186, 1984.

YAMAMOTO, K.; PEARCE, H.J. Quantitative descriptive analysis. In: MOSKOWITZ, H. Applied sensory analysis of food. New York : CRC, 1988. p.43-71.

YOUNG, L.L.; LYON, C.E. Effect of postchill and sodium tripolyphosphate on moisture binding properties, color, and Warner Bratzer shear values of chicken breast meat. Poultry Sci, Blacksburg, v.78, p.1587-1590, 1997. 